\title{
Past and present-day biogenic volatile organic compound emissions in East Asia
}

\author{
Allison Steiner*, Chao Luo ${ }^{1}$, Yan Huang, W.L. Chameides \\ School of Earth and Atmospheric Sciences, Georgia Institute of Technology, Atlanta, GA 30332, USA
}

Received 10 March 2002; accepted 3 July 2002

\begin{abstract}
Biogenic volatile organic carbon (VOC) emissions from vegetation in East Asia are estimated for two contrasting land-cover scenarios: near present-day conditions derived from satellite data and pre-disturbed land-cover based on climatological parameters and plant functional type. Hourly fluxes of isoprene and monoterpenes are calculated on a grid of $60 \mathrm{~km} \times 60 \mathrm{~km}$ cells covering much of East Asia using meteorological conditions derived from a 12-month simulation of the region using regional climate model, monthly leaf area indexes, and the Guenther et al. (J. Geophys. Res. 101 (1995) 1345) ecosystem-dependent emission factors. Total present-day isoprene emissions are estimated at approximately $12 \mathrm{Tg} \mathrm{Cyr}^{-1}$ and monoterpene emissions at $6 \mathrm{TgC}^{-1}$. These emissions are approximately 5.4 and $4 \mathrm{Tg} \mathrm{C} \mathrm{yr}^{-1}$ lower than the estimated pre-disturbed emissions of isoprene and monoterpenes, respectively, largely due to the conversion of forested land to cropland. ORVOC emission estimates for the present-day scenario, obtained by assuming a constant ORVOC emission factor for all ecosystems, are slightly higher in magnitude than isoprene emissions. Present-day totals of combined biogenic and anthropogenic VOC emissions are generally larger than biogenic VOC emissions in the pre-disturbed scenario, indicating that human activities have led to a net increase in the atmospheric source of VOC in East Asia.
\end{abstract}

(C) 2002 Elsevier Science Ltd. All rights reserved.

Keywords: Biogenic emissions; Volatile organic compounds; Asia; Land use; Isoprene

\section{Introduction}

Ground-level ozone and particulate matter typically associated with photochemical smog are formed by the photoxidation of volatile organic compounds (VOC) in the presence of nitrogen oxides $\left(\mathrm{NO}_{x}\right)$ (Haagen-Smit and Fox, 1956; NRC, 1991). The possibility that biogenic VOC could have an impact on local and regional air quality was first noted by Went (1960), who documented the emission of biogenic VOC from trees and proposed

\footnotetext{
*Corresponding author. Tel.: + 1-404-894-0838; fax: + 1404-894-1106.

E-mail address: allison@eas.gatech.edu (A. Steiner).

${ }^{1}$ Now at: Donald Bren School of Environmental Science and Management, University of California, Santa Barbara, Santa Barbara, CA 93106, USA.
}

that their oxidation could give rise to the so-called "blue hazes" often seen in forested areas. Subsequent studies further defined the speciation, magnitude, and mechanisms of biogenic VOC emissions from specific vegetation sources (Guenther et al., 1995, 2000; Harley et al., 1999; Helmig et al., 1998, 1999; Lamb et al., 1985; Rasmussen, 1972; Simpson et al., 1995, 1999; Fall and Wildermuth, 1998; Zimmerman, 1979). These detailed studies allowed other investigators to assess the relative importance of biogenic and anthropogenic VOC emissions and their respective roles in the formation of local and regionalscale photochemical smog (Chameides et al., 1988; Fehsenfeld et al., 1992; Geron et al., 1994; Lamb et al., 1987; NRC, 1991; Pierce et al., 1991, 1998; Roselle et al., 1991; Trainer et al., 1987). It has been found that, depending upon climatic conditions and land-cover characteristics, biogenic VOC emissions can be as large 
as or even larger than anthropogenic sources and, if sufficient $\mathrm{NO}_{x}$ is present, can amplify the production rates of photochemical smog.

Because biogenic VOC is emitted into the atmosphere as a by-product of natural processes, their emissions are strongly affected by ecosystem-dependent factors. Human activities such as urbanization or agriculture can change land cover, impacting the magnitude, species, and spatial distribution of vegetation. These vegetation changes translate directly into changes in biogenic VOC emissions. For example, since biogenic VOC emissions from croplands are generally less than that from forested areas (Guenther et al., 1995), growing populations and economic development within a region would be expected to lead to a decrease in biogenic VOC emissions. On the other hand, these human activities tend to increase anthropogenic VOC emissions. Thus, depending upon the relative magnitude of the biogenic and anthropogenic emissions, the total VOC emissions in a region could conceivably increase or decrease as human population and economic activity increase.

In this work, we assess the effect of human-induced land-cover changes in East Asia on the emissions of biogenic isoprene and monoterpenes. We focus on East Asia because it is one of the most populous and rapidly developing regions of the globe and is already subject to regional-scale, non-urban photochemical smog episodes (Chameides et al., 1999; Luo et al., 2000). Recently, other investigators have developed detailed inventories for the anthropogenic VOC emissions in East Asia (Klimont et al., 2002). Here we place these anthropogenic emission inventories into a larger context by developing emission inventories for biogenic VOC for present-day and pre-disturbed scenarios. Following the methodology of Guenther et al. (1995), biogenic VOC emissions from East Asia are estimated using two landcover scenarios: (i) a pre-disturbed scenario designed to mimic land cover in the region prior to large-scale agricultural or industrial development; and (ii) a present-day scenario using near-current land-cover statistics for the region.

\section{Methodology}

\subsection{Speciation}

Biogenic VOCs are often separated into four classes: isoprene $\left(\mathrm{C}_{5} \mathrm{H}_{8}\right)$, monoterpenes $\left(\mathrm{C}_{10} \mathrm{H}_{x}\right)$, other reactive VOCs (ORVOCs) $\left(\mathrm{C}_{x} \mathrm{H}_{y} \mathrm{O}_{z}\right)$, and other VOCs (OVOCs). ORVOCs and OVOCs are distinguished by their reactivity within the atmosphere with ORVOCs having atmospheric lifetimes of less than 1 day and OVOCs having lifetimes greater than 1 day. Isoprene and the monoterpenes are also quite reactive and have atmospheric lifetimes of considerably less than a day. Like most VOC, the daytime oxidation of biogenic VOC is initiated primarily by reaction with $\mathrm{OH}$, however reaction with $\mathrm{O}_{3}, \mathrm{NO}_{3}$, and $\mathrm{Cl}$ can also be important under some circumstances for some compounds (Atkinson, 1994, 1997; Atkinson and Arey, 1998; Nordmeyer et al., 1997; Paulson et al., 1992a, b).

In this work, we focus on the three reactive categories of biogenic VOC: isoprene, monoterpenes, and ORVOCs. The physiological motivation of isoprene emissions from plants is not well understood, but its production is linked indirectly to photosynthesis. Typically, isoprene is emitted from chloroplasts as soon as it is produced and light and temperature govern short-term emissions (Harley et al., 1999). Monoterpenes, on the other hand, are usually stored in pools in resin ducts or glands within the plant and usually their emission is believed to be temperature dependent only (Lerdau et al., 1997; Monson et al., 1995). In some cases, monoterpene emissions can also be light dependent and mimic the light dependence of isoprene emissions (Kesselmeier et al., 1996). The third class of compounds, ORVOCs, includes compound categories such as terpenoid alcohols, terpenoid ketones, aromatics, and sesquiterpenes. These compounds are emitted from defense tissues, during plant growth, from cut and drying vegetation, and from scented blossoms (Guenther et al., 2000).

\subsection{Spatial domain}

Biogenic VOC fluxes are calculated at the center of $589360 \mathrm{~km} \times 60 \mathrm{~km}$ cells distributed in a horizontal grid of 71 rows and 83 columns covering much of East Asia (see Fig. 1). The grid is the same as that used in the China-MAP/RegCM regional climate and chemical transport modeling system (Chameides et al., 1999; Luo et al., 2000): i.e., $60 \mathrm{~km} \times 60 \mathrm{~km}$ cells on a Lambert conformal conic projection spanning coordinates $48.42^{\circ} \mathrm{N}, 84.42^{\circ} \mathrm{E} ; 48.66^{\circ} \mathrm{N}, 154.4^{\circ} \mathrm{E} ; 14.09^{\circ} \mathrm{N}, 99.43^{\circ} \mathrm{E}$; and $14.21^{\circ} \mathrm{N}, 140.1^{\circ} \mathrm{E}$. To facilitate a more detailed analysis of our results for the eastern portion of China, we have identified five specific subregions within the overall grid; these are illustrated in Fig. 1 and will be referred to here as the Yellow River region, the Yangtze River region, the Pearl River region, the Sichuan Basin, and southeast Asia.

\subsection{Biogenic VOC flux calculations}

The biogenic VOC emission rate at a given location is typically estimated by taking the product of three parameters: (i) the quantity of leaf biomass per area; (ii) a vegetation-dependent emissions factor to represent the rate of emissions at standard conditions per unit biomass; and (iii) a meteorological factor to adjust the emissions from standard to ambient conditions. One of 


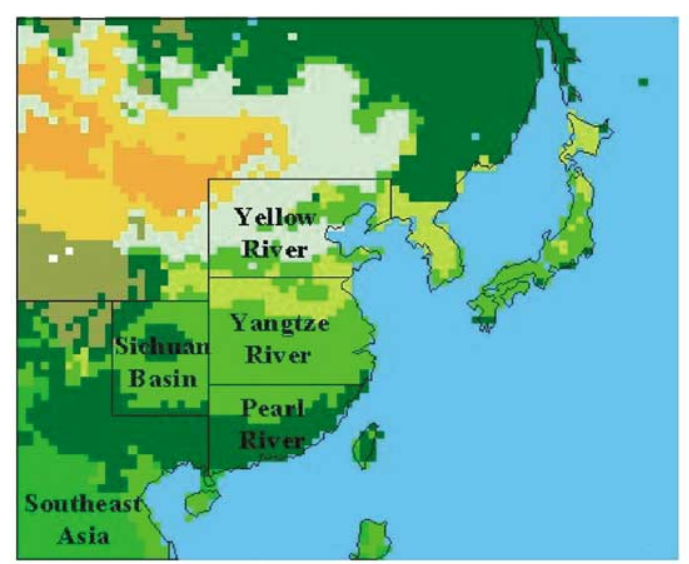

(a)

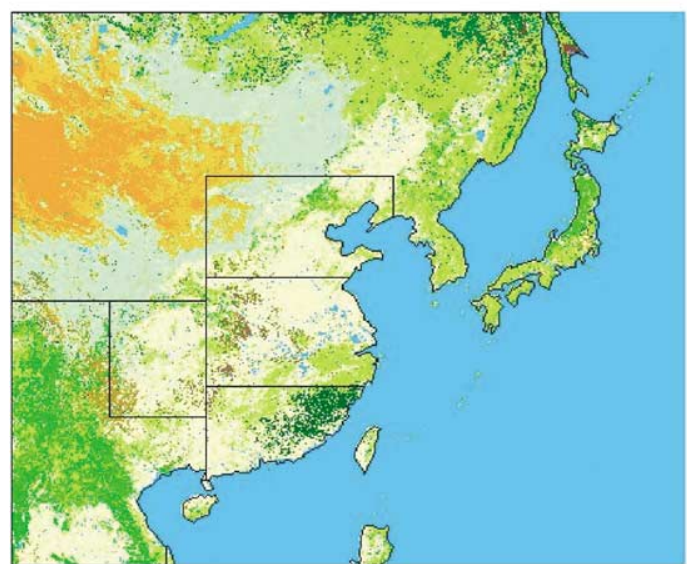

(b)

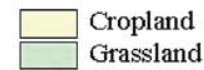

Forest (evergreen needleleaf)

Forest (deciduous broadleaf)

Forest (evergreen broadleaf)

Forest (mixed)

Shrubland

Desert

Water

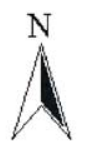

Fig. 1. The China-MAP model domain adopted here with (a) pre-disturbed land use from the BIOME data set and (b) present-day land use from $1 \mathrm{~km}$ AVHRR land cover in the Olson Global Ecosystems classification systems. Regions (Yellow River, Yangtze River, Pearl River, Sichuan Basin, and southeast Asia) are defined for the analytical purposes of this study.

the most sophisticated applications of this approach is that adopted in the Biogenic Emissions Inventory System version 2 (BEIS2) algorithm for the eastern United States (Pierce et al., 1991; Geron et al., 1994). In BEIS2, emissions are first estimated at the vegetation genus- or species-level and then summed to obtain the total emissions from all genera or species present at a given location. A somewhat less complicated approach, adopted by Guenther et al. (1995), calculates emissions at the ecosystem level using generalized ecosystemdependent emissions factors. Although the BEIS2 method provides a more detailed estimate of the VOC fluxes, it also requires much more detailed information; i.e., the distribution of biomass at the genus or species level, or emission factors for specific vegetation. Since these types of land-cover data are not readily available for East Asia and few studies have examined the emissions from different vegetation species in this region (Shao et al., 2000), we adopt here the methodology of Guenther et al. (1995). The uncertainties for this method range from a factor of three on an annual global emissions scale (Guenther et al., 1995) to a factor of five when used in a regional modeling study (Simpson et al., 1995). Additionally, uncertainties associated with emission factors can range up to a factor of five within an individual ecosystem category (Guenther et al., 1995) due to the wide variability of emissions from various vegetation types.

In Guenther et al. (1995), the biogenic flux (F), in units of $\mu \mathrm{g} \mathrm{Cm}^{-2} \mathrm{~h}^{-1}$, is represented as

$F=E_{\mathrm{f}} D c_{\mathrm{L}} c_{\mathrm{T}}$.

In our study, we utilize the emission factors $\left(E_{\mathrm{f}}\right.$, $\left.\mu \mathrm{g} \mathrm{Cg} \mathrm{g}^{-1} \mathrm{~h}^{-1}\right)$, foliar density $\left(D, g\right.$ dry matter $\left.\mathrm{m}^{-2}\right)$, and 
light and temperature correction factors $\left(c_{\mathrm{L}}\right.$ and $c_{\mathrm{T}}$, respectively) following Guenther (1997) and Guenther et al. (1995). Light and temperature correction factors are included for isoprene, while monoterpene emissions are dependent on temperature $\left(c_{\mathrm{T}}\right)$ only (i.e. $c_{\mathrm{L}}=1$ ). Light-dependent monoterpene emissions are not considered in this study. Emission factors and foliar density parameters for isoprene and monoterpenes are specified for each of 72 specific land-cover types using the Olson Global Ecosystems land-cover classification scheme following Guenther et al. (1995). Emission factors and temperature correction factors for ORVOC emission at the ecosystem level remain poorly constrained. Following Guenther et al. (1995), we adopt a constant ORVOC emission factor of $1.5 \mu \mathrm{g} \mathrm{Cg}^{-1} \mathrm{~h}^{-1}$ for all ecosystem types and ORVOC temperature correction factors equal to those for monoterpenes. Because we assume a constant ORVOC emission factor, we are unable to estimate the effect of land-cover changes on ORVOC emissions, and for this reason, we present estimates for ORVOC emissions for the present-day land-cover scenario only.

We estimate a mean monthly foliar density term, $D$, by multiplying the annual peak foliar density $\left(D_{\mathrm{p}}\right)$ by the fraction of foliar density present during the month relative to the peak $\left(D_{\mathrm{f}}\right)$ :

$D=D_{\mathrm{p}} D_{\mathrm{f}}$,

$D_{\mathrm{p}}$ is calculated from the net primary productivity (NPP) for ecosystems and an empirical, ecosystemdependent coefficient to convert NPP to a maximum annual foliar density (Guenther et al., 1995; Box, 1981). The fraction of foliar density present $\left(D_{\mathrm{f}}\right)$ is the ratio of the monthly leaf area index (LAI) to the maximum annual LAI for each model grid cell. LAI values for this study are obtained from a global LAI data set for 1994 and 1995 (Myneni et al., 1997) at a $0.5^{\circ}$ resolution. Monthly LAI and maximum annual LAI values are estimated for each model grid cell. Due to the difference in horizontal resolution of the LAI data and the model grid cells, the maximum LAI value per model grid cell was used for the calculations. Because LAI values are not available for the pre-disturbed scenario, the same LAI ratio $\left(D_{\mathrm{f}}\right)$ as the present-day study is utilized for the foliar density calculations.

\subsection{Meteorological data}

The derivation of the biogenic VOC fluxes requires specification of leaf temperature, pressure, and cloud cover fraction as a function of both time and location. These are taken from the monthly averaged values derived from a China-MAP/RegCM simulation of the model domain over the period spanning September 1994-August 1995 (Giorgi et al., 1993a, b). Note that since the model grid used in the simulation is identical to that chosen for the calculations discussed here, the RegCM results could be directly adapted to our calculations without any interpolation in the horizontal. The same meteorological data set is used for both landcover scenarios (pre-disturbed and present-day) in order to directly compare the effects of land-cover changes.

Because biogenic VOC emissions depend non-linearly on temperature and sunlight, these fluxes should be calculated, in principle, using time-dependent meteorological parameters. However, in this work as in many other regional modeling studies (cf., Lamb et al., 1987; Guenther et al., 1995), we calculate hourly biogenic fluxes using monthly averaged meteorological data for leaf temperature, pressure, and cloud cover fraction generated by the RegCM. We have assessed the probable error introduced into our calculations from the use of monthly averaged meteorological inputs by also carrying out simulations for 4 months (January, April, July and October) using hourly averaged meteorological data. The largest effects were obtained for isoprene; the use of hourly averaged meteorological inputs caused isoprene emissions to increase $20 \%$ in July, decrease $40 \%$ in January, and decrease approximately $20 \%$ in April and October. The effect on monoterpene and ORVOC emissions was much smaller; the use of hourly averaged meteorological inputs caused the emissions to decrease by $6 \%$ or less. Given the uncertainties in emission factors used to estimate biogenic VOC emissions in the region, the errors introduced into the calculation by using the meteorological approach are relatively small and acceptable for this study.

The above-canopy PAR is calculated hourly using an algorithm developed for mid-latitudes (Iqbal, 1983). This algorithm requires specification of cloud cover fraction and surface pressure, taken from the RegCM simulation. Canopy effects tend to attenuate PAR and are accounted for using the canopy model of Norman (1980). This model calculates the flux of PAR as a function of depth into the canopy, which is dependent on LAI prescribed for each grid cell. Present-day LAI (derived from Myneni et al., 1997) is used for canopy calculations, while calculated LAI (from the mean foliar density and specific leaf weight, based on Guenther et al., 1995 ) is used for the pre-disturbed scenario in order to match the vegetation present.

\subsection{Land-cover data}

Two different land-cover scenarios are used in this analysis to estimate biogenic emissions. The first utilizes a pre-disturbed land-cover derived from the BIOME model (Leemans et al., 1996), which combines climatic parameters and plant functional type to determine the land cover at $0.5^{\circ}$ resolution. In principle, this landcover classification is unaffected by agricultural or other 
human-influenced activities and thus should be a reasonable approximation of pre-disturbed conditions. Each BIOME category is matched to its equivalent Olson Global Ecosystems category for the biogenic VOC calculations.

The second land-cover scenario represents an estimate of near-current land-cover conditions as derived from 1-km AVHRR satellite data from 1992 to 1993 (EDC DAAC) for the Olson Global Ecosystems land-cover classification scheme. Land-cover data for the model domain is extracted from the Eurasia file (optimized for Asia), converted to a Lambert Conformal Conic projection and then intersected with the $60 \mathrm{~km} \times 60 \mathrm{~km}$ China-MAP grid to calculate the percentage of each land-cover type within each model grid cell. The resulting distribution of land cover over the model domain is illustrated in Fig. $1 \mathrm{~b}$.

Because the resolution of the land-cover data $(1 \mathrm{~km})$ is greater than that of the model grid $(60 \mathrm{~km})$, several different Olson ecosystem categories can be found within a model grid cell. Biogenic emissions are calculated using a "tile" approach, with up to 20 "tiles" of different ecosystems that may fall within a given model grid cell. Biogenic emissions for each model grid cell are then calculated by summing the area-weighted emissions of each "tile" within that grid cell.

In order to evaluate if the different resolutions of the input files $\left(0.5^{\circ}\right.$ versus $\left.1 \mathrm{~km}\right)$ yielded different emission rates, we compared the $1 \mathrm{~km}$ resolution present-day scenario with a coarser version where ecosystemdependent emission factors are assigned to each cell based on the most prevalent ecosystem category within that cell. This effectively decreases the land-cover resolution to $60 \mathrm{~km}$. The coarser resolution had a negligible effect on the estimated biogenic VOC fluxes, increasing isoprene emissions for the entire model domain by about $2-9 \%$, decreasing monoterpene emissions approximately $1-3 \%$, and increasing ORVOC emissions approximately $2-5 \%$.

\section{Results and discussion}

\subsection{Land-cover changes}

Fig. 1 illustrates the land-cover characteristics of the model domain for the pre-disturbed scenario (BIOME) and the present-day scenario $(1 \mathrm{~km})$. In order to evaluate the changes between the two land-cover scenarios, the original 72 Olson Global Ecosystems categories are compressed into four broad categories: forest, crop, shrub/grass, and other. The percentage of general landcover type over the entire model domain and five subregions is listed in Table 1 for both land-cover scenarios.

We estimate that human activities have led to the conversion of about $30 \%$ of the land area from forests to croplands, accompanied by a $4 \%$ loss of grass and shrubland over the entire model domain. In the Yellow River, Yangtze River, Pearl River, and Sichuan Basin subregions of China, where urban-industrial development has been especially intense in recent decades, the estimated loss of forested land is about 2-3 times as large as that estimated for the entire region (i.e., $55 \%$, $69 \%, 58 \%$, and $81 \%$, respectively). Inspection of Fig. 1 reveals that forests covered almost $100 \%$ of three of these subregions - the Yangtze River, Pearl River, and Sichuan Basin - in the pre-disturbed scenario. In the Yellow River, the loss of forested areas is accompanied by a loss of grass and shrubland from about $10 \%$ of the subregion. However, in the Yangtze River and Sichuan Basin, the forests loss has been accompanied by modest increases in grass and shrubland $(6 \%$ and $14 \%$, respectively).

\subsection{Biogenic emissions}

Emissions of isoprene and monoterpenes for the month of July for both land-cover scenarios are illustrated in Figs. 2 and 3, respectively. In Table 2,

Table 1

Percentage of land-cover category per total region area

\begin{tabular}{|c|c|c|c|c|c|c|}
\hline & Yellow River & Yangtze River & Pearl River & Sichuan Basin & Southeast Asia & Total domain \\
\hline \multicolumn{7}{|l|}{ Pre-disturbed } \\
\hline Forest & 61 & 100 & 100 & 98 & 91 & 64 \\
\hline Crop & 0 & 0 & 0 & 0 & 0 & 0 \\
\hline Grass/shrub & 34 & 0 & 0 & 2 & 9 & 19 \\
\hline Other & 5 & 0 & 0 & 0 & 0 & 17 \\
\hline \multicolumn{7}{|l|}{ Present-day } \\
\hline Forest & 6 & 31 & 42 & 17 & 53 & 33 \\
\hline Crop & 59 & 62 & 56 & 53 & 31 & 27 \\
\hline Grass/shrub & 24 & 6 & 1 & 16 & 7 & 15 \\
\hline Other & 11 & 1 & 1 & 14 & 9 & 25 \\
\hline
\end{tabular}


annual emission rates of isoprene and monoterpenes over the entire domain and five subregions for both land-cover scenarios are listed and compared to estimated annual present-day anthropogenic VOC emission rates. As noted earlier, ORVOC emissions are difficult to quantify on the ecosystem level, and thus estimates of ORVOC emissions are provided only for the present-day scenario in Table 2.

Present-day biogenic emissions of isoprene, monoterpenes, and ORVOCs within the model domain are estimated at 12,6, and $17 \mathrm{TgC}^{-1}$, respectively. The relatively large ORVOC emission rate is likely an artifact arising from our assumption of a constant ORVOC emission factor for all ecosystem categories. This result highlights the need for more detailed data on the ORVOC emissions from specific types of vegetation as well as emission factors on the ecosystem-level. Within the model domain, the heavily forested and relatively warm southeast Asia subregion is by far the most prolific source of biogenic VOC, accounting for roughly $50 \%, 30 \%$, and $40 \%$ of the model domain's total emissions of isoprene, monoterpenes, and OR-

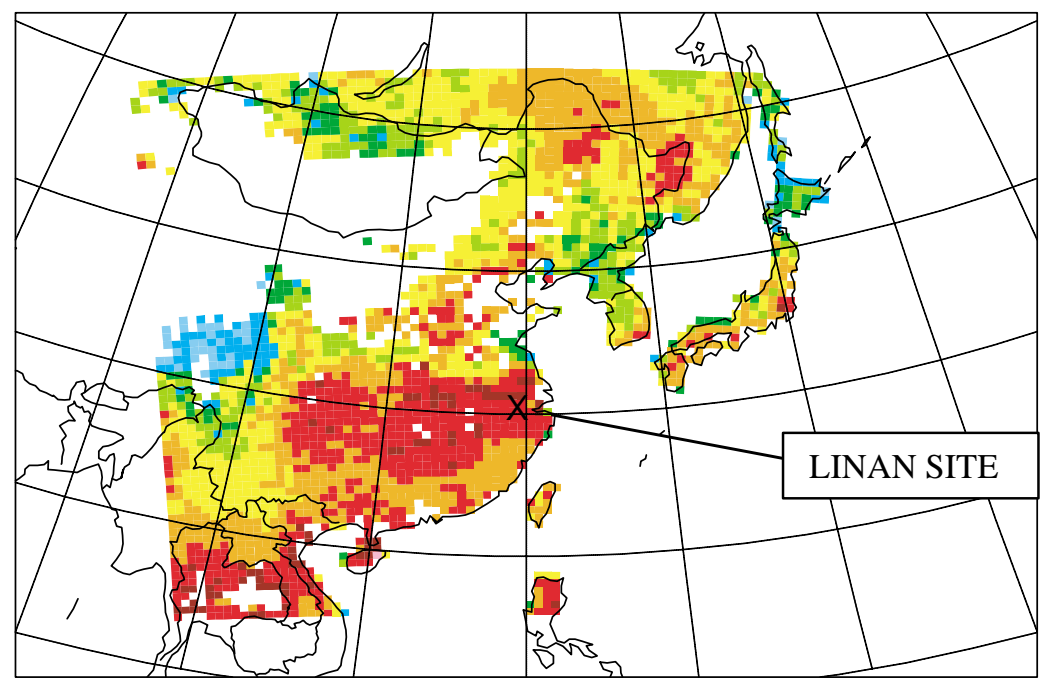

(a)

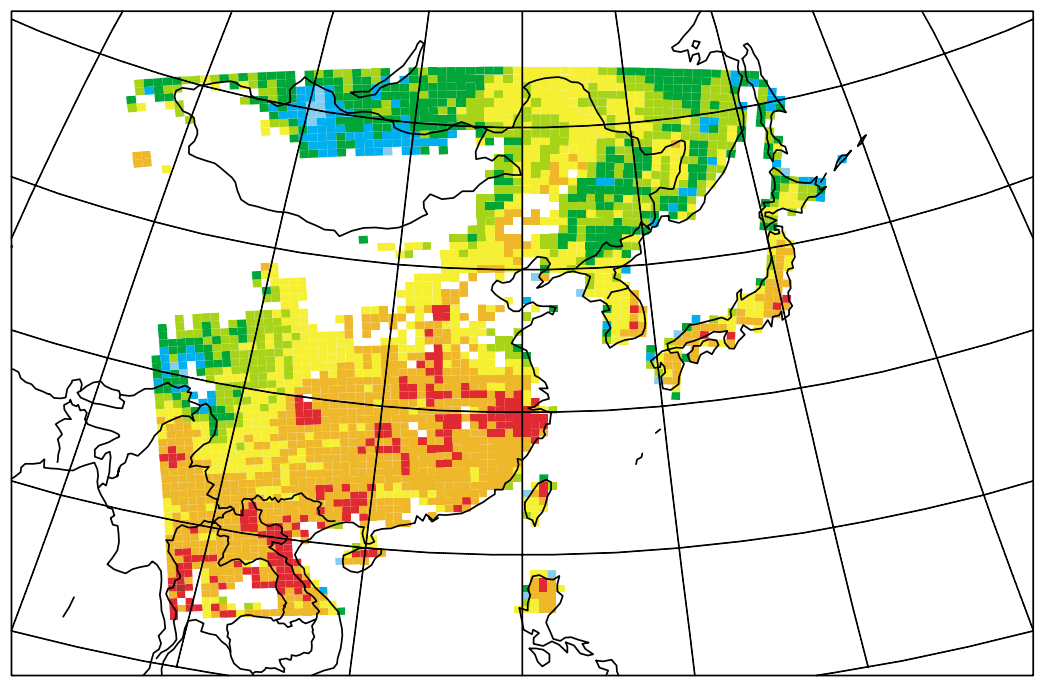

(b)

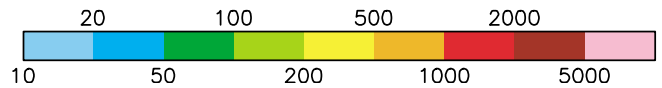

Fig. 2. July meteorological averages of isoprene flux $\left(\mu \mathrm{g} \mathrm{C} \mathrm{m}^{-2} \mathrm{~h}^{-1}\right)$ for the (a) pre-disturbed land-cover scenario and (b) present-day land-cover scenario. 


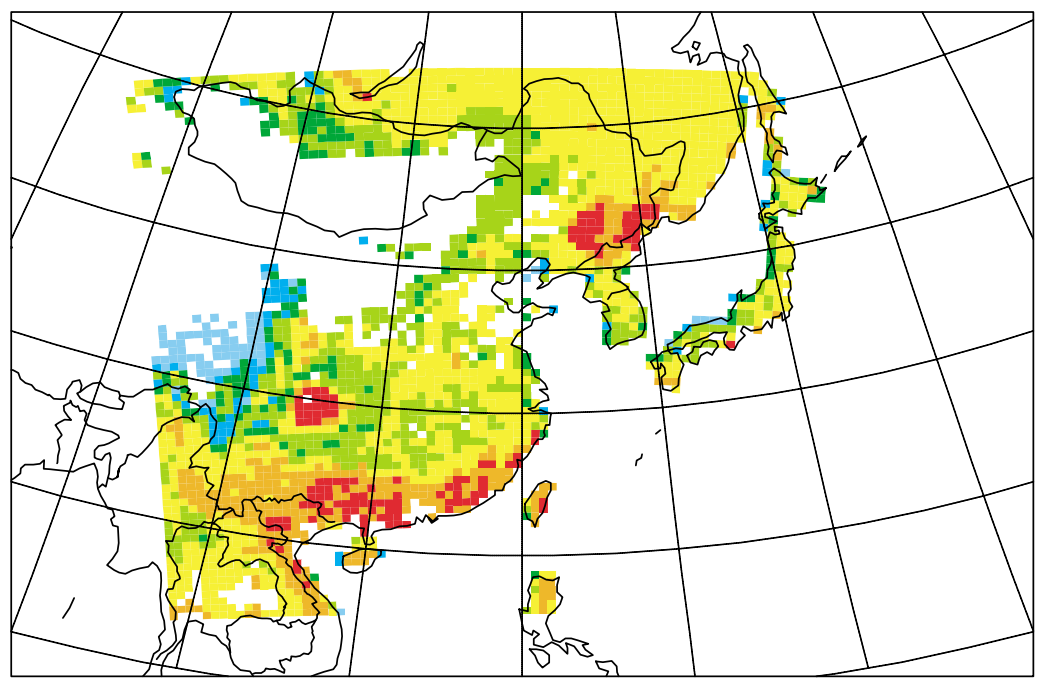

(a)

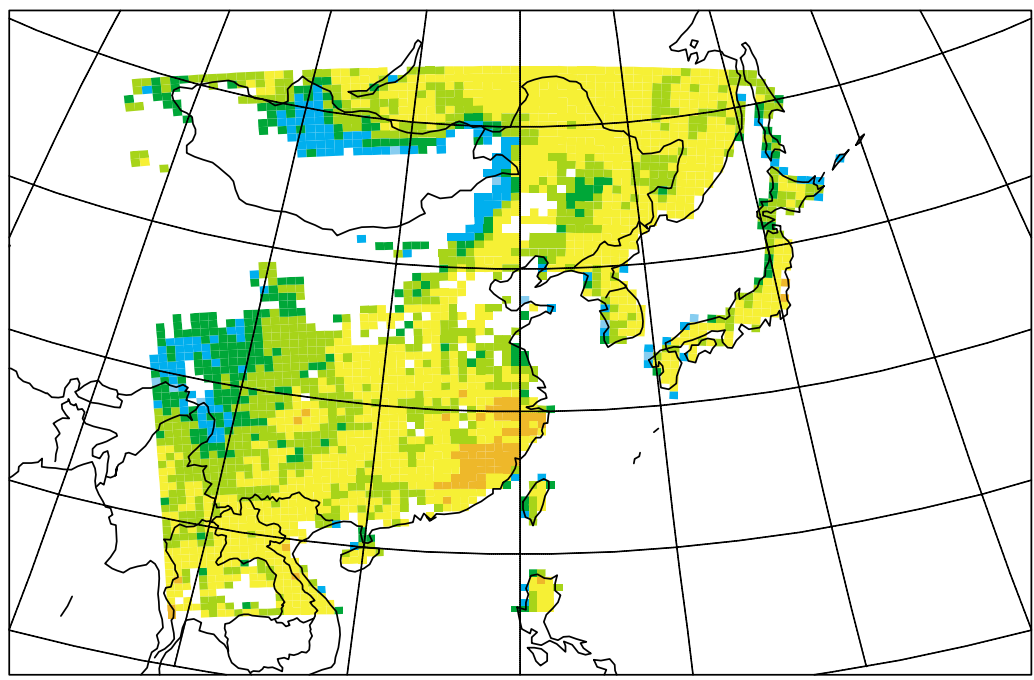

(b)

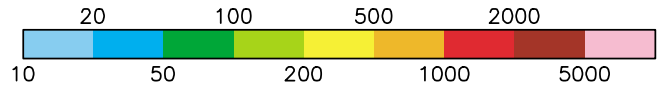

Fig. 3. July meteorological averages of monoterpene flux $\left(\mu \mathrm{g} \mathrm{C}^{-2} \mathrm{~h}^{-1}\right)$ for the (a) pre-disturbed land-cover scenario and (b) presentday land-cover scenario.

VOCs, respectively. Within China, the Yangtze and Pearl River subregions represent the largest sources of biogenic VOC.

We estimate that total annual isoprene emissions for the pre-disturbed case were $17 \mathrm{TgC}^{-1}$ and monoterpene emissions were $10 \mathrm{Tg} \mathrm{Cyr}^{-1}$. This suggests that present-day isoprene and monoterpene emissions in East Asia have decreased by about $30 \%$ and $40 \%$, respectively, as a result of human-induced land-cover changes.
Overall, these decreases correspond to a $34 \%$ decrease in the flux of organic carbon to the atmosphere.

Comparing the pre-disturbed to the present-day scenario, we find that isoprene emissions decrease throughout the model domain. The spatial distribution of the isoprene decrease generally follows the loss of the high isoprene-emitting deciduous and mixed forestland cover (see Fig. 1). In the Sichuan Basin where $80 \%$ of the subregion is estimated to have been converted from 
Table 2

Annual biogenic emissions $\left(\mathrm{Tg} \mathrm{Cyr}^{-1}\right)$ for pre-disturbed and present-day land-cover scenarios, and comparison of these emissions to present-day anthropogenic VOC emissions

Yellow River Yangtze River Pearl River Sichuan Basin Southeast Asia Rest of domain Total

\begin{tabular}{|c|c|c|c|c|c|c|c|}
\hline \multicolumn{8}{|l|}{ A. Biogenics } \\
\hline \multicolumn{8}{|l|}{ Pre-disturbed } \\
\hline Isoprene & 0.69 & 2.44 & 1.55 & 1.44 & 7.28 & 4.01 & 17.41 \\
\hline Monoterpenes & 0.26 & 0.58 & 1.12 & 0.58 & 4.22 & 3.51 & 10.26 \\
\hline Total Biogenics & 0.95 & 3.02 & 2.67 & 2.02 & 11.50 & 7.52 & 27.67 \\
\hline \multicolumn{8}{|l|}{ Present-day } \\
\hline Isoprene & 0.47 & 1.65 & 1.08 & 0.84 & 5.91 & 2.03 & 11.98 \\
\hline Monoterpenes & 0.23 & 0.72 & 0.69 & 0.33 & 2.22 & 2.02 & 6.20 \\
\hline ORVOCs $^{\mathrm{a}}$ & 0.83 & 2.17 & 1.47 & 0.96 & 6.82 & 4.38 & 16.62 \\
\hline Total Biogenics & 0.70 & 2.37 & 1.77 & 1.17 & 8.13 & 4.05 & 18.18 \\
\hline \multicolumn{8}{|c|}{ Present-day_-Pre-disturbed } \\
\hline Total Biogenics & -0.25 & -0.65 & -0.90 & -0.84 & -3.4 & -3.5 & -9.5 \\
\hline$\%$ change & -26 & -22 & -34 & -42 & -29 & -46 & -34 \\
\hline B. Anthropogenic ${ }^{\mathrm{b}}$ & 3.08 & 5.07 & 2.34 & 1.96 & 0.91 & 2.53 & 15.89 \\
\hline
\end{tabular}

forests to croplands and other landscapes, present-day isoprene emissions are calculated to be about $40 \%$ lower than that of the pre-disturbed case. In the southeast Asia subregion, only about $40 \%$ of the area was converted from forests and the decrease in isoprene emissions is more modest (i.e., 20\%). In July (see Fig. 2), isoprene emissions for the pre-disturbed scenario are greater in the Yangtze region and in northern China because of the large presence of deciduous forests in the pre-disturbed land cover. Along the northern border of China, the previously forested areas with high isoprene emission factors were converted to mixed forest/cropland in the present-day scenario, resulting in lower isoprene emissions in the northern portion of the domain. However, despite the loss of deciduous forested land, strong isoprene emissions (500-2000 $\mu \mathrm{g} \mathrm{C} \mathrm{m}^{-2} \mathrm{~h}^{-1}$ ) are still seen throughout central and southern China.

Monoterpene emissions also decrease across the model domain and most, but not all, subregions. Decreases in monoterpene emissions are seen in Yellow

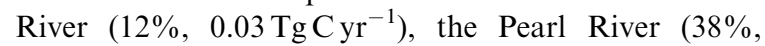
$\left.0.4 \mathrm{TgC}^{-1}\right)$, the Sichuan Basin $\left(43 \%, 0.25 \mathrm{Tg} \mathrm{C} \mathrm{yr}^{-1}\right)$, and southeast Asia $\left(47 \%, 2 \mathrm{Tg} \mathrm{C} \mathrm{yr}^{-1}\right)$. A slight increase of about $19 \% \quad\left(0.14{\left.\mathrm{TgC} \mathrm{yr}^{-1}\right)}^{-1}\right.$ is obtained for the Yangtze River subregion. It is interesting to note the contrasting trends in isoprene and monoterpene emissions in the various subregions. In the Yellow River and Yangtze River, the percentage decrease in monoterpene emissions is smaller than the isoprene decrease (in fact, in the Yangtze River subregion, monoterpene emissions actually increase). In addition to the general loss of forested areas in these subregions, a significant fraction of the high-isoprene emitting deciduous forests in the pre-disturbed scenario was converted to mixed forests and shrubland in the present-day scenario. The latter land-cover types emit much less isoprene but still have significant monoterpene emissions, and thus the decrease in monoterpene emissions is smaller than that of isoprene. In the Sichuan Basin, Pearl River, and southeast Asia subregions, the decrease in monoterpene emissions was as large as or greater than the decrease in isoprene emissions. Inspection of Fig. 1 indicates that these regions had significant amounts of evergreen forests in the pre-disturbed cases that were converted to croplands and grass/shrubland. Evergreen forests emit large amount of monoterpenes, but very little isoprene and, hence in these cases, the decrease in monoterpene emissions was more pronounced. During July, the month of maximum annual emissions, the most significant changes in monoterpene emissions (Fig. 3) are along the lower coastline of China (specifically, the Pearl River region) and the Sichuan Basin region. The monoterpene emissions in Fig. 3 match the respective land-cover characteristics in Fig. 1, where the areas of high monoterpene emissions arise in the locations of evergreen forest (e.g., the western portion of the Pearl River subregion).

Estimates of the present-day annual anthropogenic VOC emission rates, derived from the emissions inventory of Streets and Waldhoff (1999), are also listed in Table 2 for each geographic subregion and the entire domain. Over the entire domain, biogenic emissions are 
greater than the anthropogenic emissions. In the Yellow and Yangtze River regions, the anthropogenic VOC emissions outweigh the biogenic emissions on an annual basis, while the biogenic emissions in southeast Asia are much greater than their anthropogenic counterpart. Comparison of the anthropogenic and biogenic emissions indicates that: (i) present-day biogenic emissions are similar in magnitude to anthropogenic emissions and thus should be included in regional air pollution assessments in East Asia; and (ii) the sum of presentday biogenic and anthropogenic VOC emissions are greater than the biogenic VOC emissions in the predisturbed scenario, and thus it is estimated that the total flux of VOC to the region has increased as a result of human activities.

\subsection{Comparison of modeled isoprene fluxes with fluxes inferred from observations}

Ideally, our model results could be evaluated by directly comparing our calculated fluxes with measurements of biogenic VOC fluxes. Unfortunately, direct measurements of these fluxes over East Asian ecosystems are not readily available. Therefore, we attempt to verify the robustness of our modeling results by comparing them with an independently derived flux from ground-based observations of ambient isoprene concentrations. These isoprene measurements were performed at the rural Linan site in eastern China during the spring and early summer of 2001 (D.R. Blake, pers. comm., 2002). The Linan site is located approximately $10 \mathrm{~km}$ north of the Linan county township (population $\sim 50,000$ ), $50 \mathrm{~km}$ northwest of Hangzhou and $250 \mathrm{~km}$ southwest of Shanghai (Luo et al., 2000; Wang et al., 2001; location labeled in Fig. 2). Although the site is in proximity of highly populated areas, the sampling site itself is in a rural location surrounded by agricultural activity, making it an ideal candidate to examine biogenic VOC emissions.

To compare these measurements to our modeling results, we used the average isoprene concentration (880 pptv) obtained from 14 mid-day samples collected between the hours of 12 and 5PM (local time) during the first 10 days of June 2001. Our model calculations yielded an average mid-day isoprene flux of $2000 \mu \mathrm{g} \mathrm{C} \mathrm{m}^{-2} \mathrm{~h}^{-1}$ from the grid cell containing the Linan site during early June. We then used this concentration to estimate the isoprene flux $(F$, $\mu \mathrm{g} \mathrm{m}^{-2} \mathrm{~h}^{-1}$ ) assuming that $\mathrm{OH}$ is the primary oxidation pathway for isoprene:

$F=\overline{C_{\text {iso }}} k_{\mathrm{OH}, \text { iso }}[\mathrm{OH}] H$,

where $\overline{C_{\text {iso }}}$ is the vertically averaged isoprene concentration over a boundary-layer height $(H)$ assumed to be $1 \mathrm{~km}, k_{\mathrm{OH} \text {,iso }}$ is the rate constant for the reaction of $\mathrm{OH}$ with isoprene, and $[\mathrm{OH}]$ is the concentration of $\mathrm{OH}$ (assumed to be constant over the boundary layer). In our calculations, we estimated $\overline{C_{\text {iso }}}$ using a simple eddydiffusion parameterization to simulate the competing effects of vertical transport and a first-order chemical loss with OH (see Chameides et al. (1992) and references cited therein). We adopted a value of $7.6 \mathrm{E}+06$ molecules $\mathrm{cm}^{-3}$ for $[\mathrm{OH}]$, based on the average midday $\mathrm{OH}$ concentration calculated by the ChinaMAP/ RegCM model in early June 1995 at Linan. The isoprene- $\mathrm{OH}$ reaction rate constant $\left(k_{\mathrm{OH} \text {,iso }}\right)$ was specified as $1.01 \mathrm{E}-10 \mathrm{~cm}^{3}$ molecules ${ }^{-1} \mathrm{~s}^{-1}$, based on a surface level temperature of $297 \mathrm{~K}$ (Atkinson, 1994; Paulson and Seinfeld, 1992). With these assumptions, we obtained a vertically averaged isoprene concentration of $380 \mathrm{pptv}$ and an inferred flux of $2600 \mu \mathrm{g} \mathrm{Cm}^{-2} \mathrm{~h}^{-1}$. This flux is reasonably consistent with the mid-day average modeled flux of $2000 \mu \mathrm{g} \mathrm{C} \mathrm{m}{ }^{-2} \mathrm{~h}^{-1}$.

\section{Conclusions}

We estimate that forested land cover has decreased in East Asia as a result of human activities by approximately $30 \%$ over the entire domain, but up to $70 \%$ and $80 \%$ in the Yangtze River and Sichuan Basin regions. A model assessment of the impacts of these land-cover changes on biogenic VOC emissions in East Asia indicate that annual isoprene and monoterpene emissions have decreased by about $30 \%$ and $40 \%$, respectively. However, these changes are not uniform throughout the region. For example, large decreases in both isoprene and monoterpene emissions are predicted for the Sichuan Basin where more than $80 \%$ of the forested areas have been converted to croplands and grasslands and a significant fraction of the pre-disturbed forests were composed monoterpene-emitting evergreens. In the Yangtze River region, on the other hand, more modest decreases in total biogenic emissions (of $\sim 22 \%$ ) are predicted with a $20 \%$ increase in monoterpene emissions. In this case, we estimated that a significant fraction of the high-isoprene emitting deciduous forests in the pre-disturbed scenario was converted to mixed forests and shrubland in the present-day scenario. Despite, the overall large decreases in biogenic emissions, present-day anthropogenic VOC emissions more than make up for the decrease and we therefore estimate that the present-day total emissions of VOC in East Asia have increased as a result of human activities.

A complete understanding of the effects of these VOC emission changes on regional air quality in East Asia will require more comprehensive regional chemical modeling beyond the scope of this study. Nevertheless, some general trends can be noted. Luo et al. (2000) found that regional ground-level ozone 
pollution episodes over East Asia are most intense during the fall and spring. During these periods, VOClimitation most likely applies on regional scales in the northern portion of the Yangtze River as well as the Yellow River region. We predict that the overall VOC emissions in these regions have increased considerably as a result of anthropogenic activities, and thus, this increase (in conjunction with anthropogenic $\mathrm{NO}_{x}$ emissions) have likely had a negative impact on regional air quality. It is also interesting to note, in this regard, that we predict an increase in monoterpene emissions in the Yangtze River region, where fine particle pollution appears to be especially severe (Chameides et al., 2002). Unlike isoprene, monoterpene oxidation products can undergo gas-toparticle conversion, forming fine particulate matter. Thus it is conceivable that changes in land cover over the Yangtze River region may have indirectly exacerbated regional fine particle pollution by enhancing monoterpene emissions.

ORVOC emissions represent a major source of uncertainty in our analysis. At present there is very limited information on how these emissions vary across ecosystems, which has precluded our estimation of the ORVOC response to land-cover changes over East Asia. Nevertheless, a preliminary estimate of present-day ORVOC emissions assuming a constant emission factor for all ecosystems suggests that ORVOC emissions could be quite significant, as large or even larger than that of isoprene. Further investigation into specific ORVOC compounds from specific ecosystems, as well as further isoprene and monoterpene emissions testing in East Asia, could provide better and more reliable estimates of total biogenic VOC emissions, their response to landcover changes, and their impact on regional atmospheric chemistry.

\section{Acknowledgements}

This work was supported in part by funds from the National Aeronautics and Space Administration under Grant NAG5-3855 for the China-MAP research project and by funds from the National Science Foundation under Grant ATM-9617378.

\section{References}

Atkinson, R., 1994. Gas-phase tropospheric chemistry of organic components. Journal of Physical and Chemical Reference Data, Monographs (2), 1-216.

Atkinson, R., 1997. Gas-phase tropospheric chemistry of volatile organic compounds: 1. Alkanes and alkenes. Journal of Physical and Chemical Reference Data 26 (2), 215-290.
Atkinson, R., Arey, J., 1998. Atmospheric chemistry of biogenic organic compounds. Accounts of Chemical Research 31, 574-583.

Box, E., 1981. Foliar biomass: data base of the international biological program and other sources. In: Bufalini, J., Arnts, R. (Eds.), Atmospheric Biogenic Hydrocarbons. Butterworth, Stoneham, MA.

Chameides, W.L., Lindsay, R.W., Richardson, J., Kiang, C.S., 1988. The role of biogenic hydrocarbons in urban photochemical smog: Atlanta as a case study. Science 241, 1473-1475.

Chameides, W.L., et al., 1992. Ozone precursor relationships in the ambient atmosphere. Journal of Geophysical Research 97, 6037-6055.

Chameides, W.L., et al., 1999. Is ozone pollution affecting crop yields in China? Geophysical Research Letters 26, 867-870.

Chameides, W.L., et al., 2002. Correlation between modelcalculated anthropogenic aerosols and satellite-derived cloud optical depths: Indication of indirect effect? Journal of Geophysical Research 107, 10.1029/2000JD000208.

EDC DAAC, Earth resources observing system Data Center Distributed Active Archive. http://edcwww.cr.usgs.gov/ landdaac/glcc/glcc.html.

Fall, R., Wildermuth, M.C., 1998. Isoprene synthase: from biochemical mechanism to emission algorithm. Journal of Geophysical Research 103, 25599-25609.

Fehsenfeld, F., et al., 1992. Emissions of volatile organic compounds from vegetation and their implications for atmospheric chemistry. Global Biogeochemical Cycles 6, 389-430.

Geron, C.D., Guenther, A.B., Pierce, T.E., 1994. An improved model for estimating emissions of volatile organic compounds from forests in the eastern United States. Journal of Geophysical Research 99, 12773-12791.

Giorgi, F., Marinucci, M.R., Bates, G.T., 1993a. Development of a second generation regional climate model (RegCM2), boundary-layer and radiative processes. Monthly Weather Review 121, 2794-2813.

Giorgi, F., Marinucci, M.R., Bates, G.T., De Canio, G., 1993 b. Development of a second generation regional climate model (RegCM2), convective processes and assimilation of lateral boundary conditions. Monthly Weather Review 121, 2814-2832.

Guenther, A., 1997. Seasonal and spatial variations in natural volatile organic compound emissions. Ecological Applications 7 (1), 34-45.

Guenther, A., et al., 1995. A global model of natural volatile organic compound emissions. Journal of Geophysical Research 101, 1345-1359.

Guenther, et al., 2000. Natural emissions of non-methane volatile organic compounds, carbon monoxide, and oxides of nitrogen from North America. Atmospheric Environment 34, 2205-2230.

Haagen-Smit, A.J., Fox, M.M., 1956. Ozone formation in photochemical oxidation of organic substances. Industrial and Engineering Chemistry 48, 1484-1487.

Harley, P.C., Monson, R.K., Lerdau, M.T., 1999. Ecological and evolutionary aspects of isoprene emissions from plants. Oecologia 118, 109-123. 
Helmig, D., et al., 1998. Vertical profiling and determination of landscape fluxes of biogenic non-methane hydrocarbons within the planetary boundary layer in the Peruvian Amazon. Journal of Geophysical Research 103, 25519-25532.

Helmig, D., et al., 1999. Biogenic volatile organic compound emissions (BVOCs), I. Identifications from three continental sites in the US. Chemosphere 38, 2163-2187.

Iqbal, M., 1983. An Introduction to Solar Radiation. Academic, San Diego, CA.

Kesselmeier, J., et al., 1996. Emission of monoterpenes and isoprene from a Mediterranean oak species Quercus ilux $L$. measured within the BEMA project. Atmospheric Environment 30, 1841-1850.

Klimont, Z., et al., 2002. Anthropogenic emissions of nonmethane volatile organic compounds in China. Atmospheric Environment 36, 1309-1322.

Lamb, B., Westberg, H., Allwine, G., 1985. Biogenic hydrocarbon emissions from deciduous and coniferous tees in the United States. Journal of Geophysical Research 90, 2380-2390.

Lamb, B., Guenther, A., Gay, D., Westberg, H., 1987. A national inventory of biogenic hydrocarbon emissions. Atmospheric Environment 21, 1695-1705.

Leemans, R., Cramer, W., Van Minnen, J.G., 1996. Prediction of global biome distribution using bioclimatic equilibrium models. In: Breymeyer, A.I., Hall, D.O., Melillo, J.M., Agren, G.I. (Eds.), Global Change: Effects on Coniferous Forests and Grasslands. Wiley, New York, pp. 413-445.

Lerdau, M., Guenther, A., Monson, R., 1997. Plant production and emission of volatile organic compounds. Bioscience 47, 373-383.

Luo, C., et al., 2000. A non-urban ozone air pollution episode over eastern china: observations and model simulations. Journal of Geophysical Research 105, 1889-1908.

Monson, R.K., Lerdau, M.T., Sharkey, T.D., Schimel, D.S., Fall, R., 1995. Biological aspects of constructing volatile organic compound emission inventories. Atmospheric Environment 29, 2989-3002.

Myneni, R.B., Nemani, R.R., Running, S.W., 1997. Estimation of global leaf area index and absorbed PAR using radiative transfer models. IEEE Transactions on Geoscience and Remote Sensing 35, 1380-1393.

National Research Council, 1991. Rethinking the Ozone Problem in Urban and Regional Air Pollution, National Academy of Sciences Press, Washington, DC, 500pp.

Nordmeyer, T., et al., 1997. Unique products of the reaction of isoprene with atomic chlorine: potential markers of chlorine atom chemistry. Geophysical Research Letters 24, 1615-1618.

Norman, J.M., 1980. Interfacing leaf and canopy light interception models. In: Hesketh, J.D., Jones, J.W. (Eds.), Predicting Photosynthesis for Ecosystem Models., Vol. II. CRC Press, Boca Raton, FL.
Paulson, S.E., Seinfeld, J.H., 1992. Development and evaluation of a photoxidation mechanism for isoprene. Journal of Geophysical Research 97, 703-715.

Paulson, S.E., Flagan, R.C., Seinfeld, J.H., 1992a. Atmospheric photooxidation of isoprene, Part I: the hydroxyl radical and ground state atomic oxygen reactions. International Journal of Chemical Kinetics 24, 79-101.

Paulson, S.E., Flagan, R.C., Seinfeld, J.H., 1992b. Atmospheric photooxidation of isoprene, Part II: the ozone-isoprene reaction. International Journal of Chemical Kinetics 24, 103-125.

Pierce, T., Lamb, B., van Meter, A., 1991. Development of a biogenic emissions inventory system for regional scale air pollution models. Paper Presented at Proceedings of the 83rd Air and Waste Management Association Annual Meeting. Air and Waste Management Association, Pittsburgh, Penn.

Pierce, T., et al., 1998. Influence of increased isoprene emissions on regional ozone modeling. Journal of Geophysical Research 103, 25611-25639.

Rasmussen, R., 1972. What do hydrocarbons from trees contribute to air pollution? Journal of the Air Pollution Control Association 7, 537-543.

Roselle, S., Pierce, T., Schere, K., 1991. The sensitivity of regional ozone modeling to biogenic hydrocarbons. Journal of Geophysical Research 96, 7371-7394.

Shao, M., et al., 2000. Biogenic VOCs emissions and its impact on ozone formation in major cities of China. Journal of Environmental Science and Health A 35 (10), 1941-1950.

Simpson, D., Guenther, A., Hewitt, C.N., Steinbrecher, R., 1995. Biogenic emissions in Europe, 1. Estimates and uncertainties. Journal of Geophysical Research 100, 22875-22890.

Simpson, D., et al., 1999. Inventorying emissions from nature in Europe. Journal of Geophysical Research 104, 8113-8152.

Streets, D.G., Waldhoff, S.T., 1999. Emissions of anthropogenic VOCs in China in 1995 and 2020. Draft Final Report, China-MAP project, Argonne National Laboratory, Decision and Information Science Division, January 1999.

Trainer, M., et al., 1987. Models and observations of the impact of natural hydrocarbons on rural ozone. Nature 329, 705-707.

Wang, T., Vincent, T.F., Anson, M., Li, Y.S., 2001. Ozone and related gaseous pollutants in the boundary layer of eastern China: overview of the recent measurements at a rural site. Geophysical Research Letters 28, 2373-2376.

Went, F., 1960. Blue haze in the atmosphere. Nature 187, 641-643.

Zimmerman, P.R., 1979. Testing of hydrocarbon emissions from vegetation, leaf litter and aquatic surfaces, and development of a methodology for compiling biogenic emission inventories. Report EPA-450-4-70-004, US Environmental Protection Agency, Washington, DC. 